\title{
Deep mixing method for the construction of earth and water retaining
} walls

\author{
Nicolas Denies ${ }^{a^{*}}$, Noël Huybrechts ${ }^{a, b}$ \\ a Belgian Building Research Institute, Geotechnical Division, 21, av. P. Holoffe, 1342/Limelette, Belgium \\ ${ }^{\mathrm{b}} \mathrm{KU}$ Leuven
}

Received: 14 March 2017 / Accepted: 09 August 2017 / Published online: 21 September 2017

(C) The Author(s) 2017. This article is published with open access and licensed under a Creative Commons Attribution 4.0 International License.

\begin{abstract}
In the deep mixing method, the ground is mechanically mixed in place while a binder, often based on cement, is injected. After hardening of the soilcement mixture, called soil mix material, soil mix elements are formed in the ground. Originally known as a ground improvement technique, the deep mixing is more and more applied for the construction of earth-water retaining structures within the framework of excavation works.

After a short introduction to the execution aspects of the method, the authors discuss the hydro-mechanical properties of the soil mix material mainly based on the results of the BBRI Soil Mix project (2009-2013). A design approach dedicated to the soil mix retaining walls and developed in collaboration with the SBRCURnet is then presented. In this methodology, which is in line with the structural Eurocodes, design rules are adapted to the functions of the soil mix wall (earth-water retaining, bearing and cut-off functions) including the temporary or permanent character of the application. Based on the result of large-scale bending tests, the interaction between the soil mix material and the steel reinforcement is considered in the calculations allowing a reduction of the steel section between 10 and $40 \%$.
\end{abstract}

Keywords: Deep mixing; Soil mix retaining wall; Mechanical characterization; Design approach

\section{Introduction}

In the deep mixing method, the ground is mechanically mixed in place and in depth by an auger or a cutter machine (see Fig. 1), while a binder, often based on cement, is injected. After hardening of the soil-cement mixture, called soil mix material, cylindrical soil-cement columns or rectangular soil mix panels are formed in the ground.

Since several decades, the deep mixing method has been known as a ground improvement technique. Numerous literature reviews have been written concerning the deep mixing method [1-16]. The results of international and European research programs have also been published [17, 18], while the European standard for the execution of deep mixing "Execution of special geotechnical works - Deep Mixing" [19] was published in 2005.

Originally used for ground improvement of soft cohesive soils (such as clay, silt and peat), the deep mixing method is since the beginning of the twenty-first century more and more applied for the construction of earth-water retaining structures within the framework of excavation works (see Fig. 2). The success of this new application is based on the recent advances in the deep mixing equipment coupled with the development of binders allowing to reach typical unconfined compressive strength of 1 to $12 \mathrm{MPa}$ for the soil mix material. In order to build soil mix walls for the realization of an excavation, the cylindrical soil-cement columns or the rectangular soil mix panels are placed next to each other, in a secant way such as illustrated in Fig. 2. By overlapping the different soil mix elements, a continuous soil mix wall is built. The soil mix wall is then horizontally stabilized by shoring or anchoring. During execution, steel beams are installed into the fresh soil mix material to resist the shear forces and bending moments due to the earthwater pressure applying on the retaining wall. The soil mix material transmits the stresses due to this earth-water pressure to the steel beams by way of an arching effect developing in the soil mix material due to the difference of stiffness between the steel and the soil mix material. Figure 3 illustrates the working principle of a soil mix retaining wall.

\footnotetext{
* Corresponding author: Nicolas Denies, E-mail: nde@bbri.be
} 


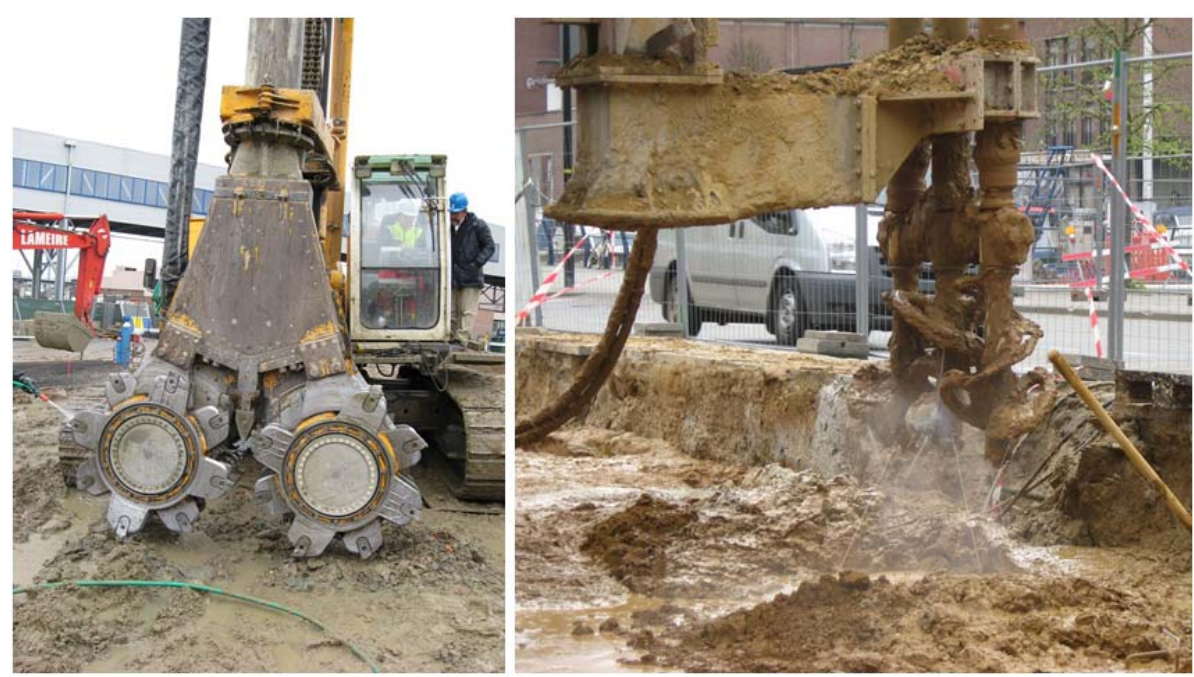

Figure 1. Illustration of typical deep mixing equipment in action on Belgian construction sites: Cutter Soil Mix (CSM) system of Bauer (left) and triple shaft configuration TSM system of Smet F\&C (right).
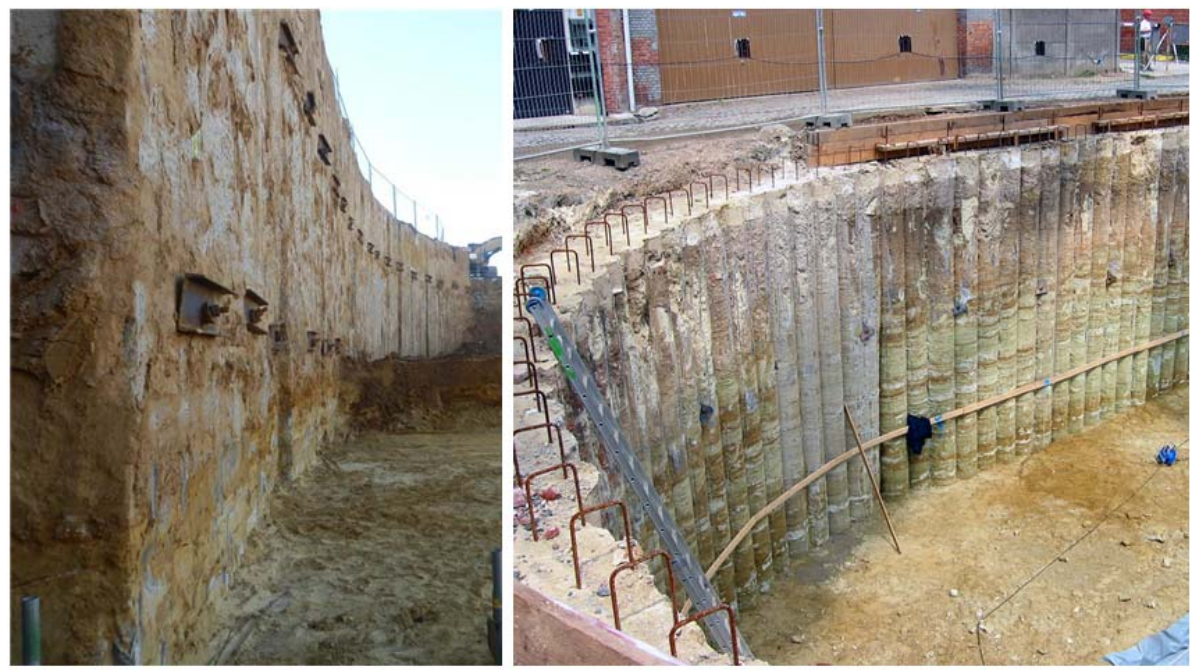

Figure 2. Soil mix retaining walls within the framework of excavation works in Belgium: soil mix walls built with CSM-panels (left) and with the C-mix shaft system of CVR nv (right).

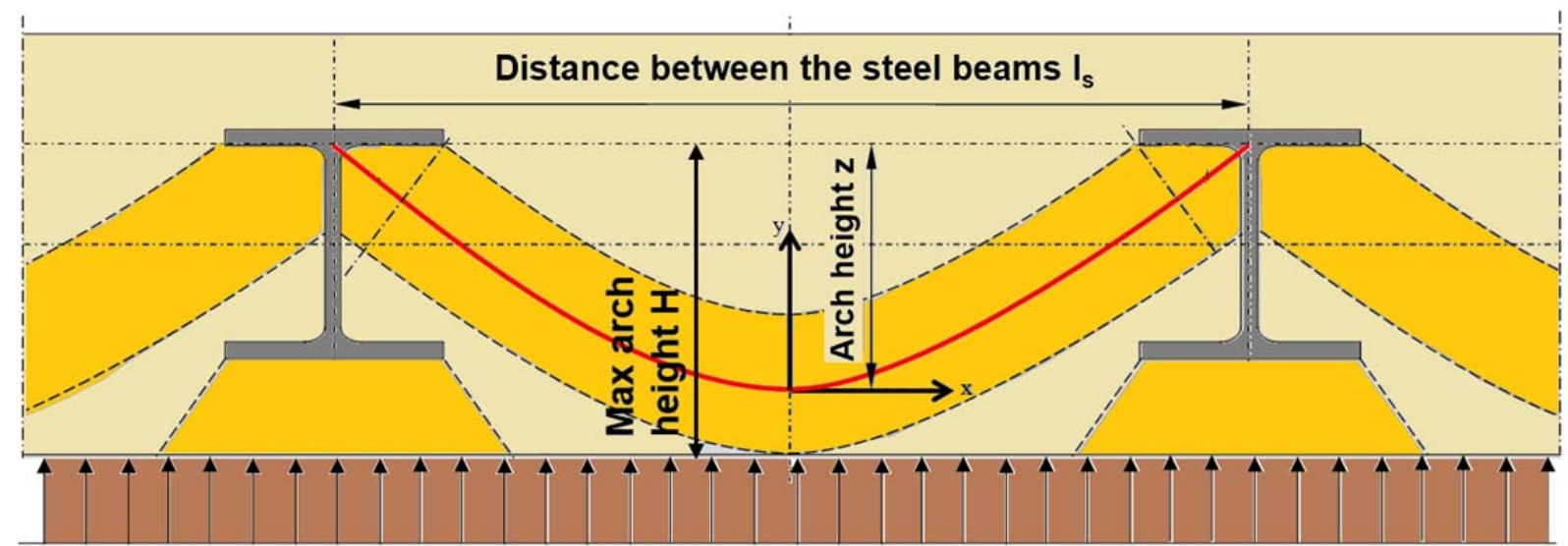

\section{Earth and water pressures}

Figure 3. Working principle of a soil mix retaining wall: illustration of the arching effect. 


\section{Hydro mechanical characterization of the soil mix material used for the construction of retaining walls}

The main structural difference between a soil mix wall and a traditional secant concrete pile walls is the constitutive soil mix material which consists of a soil - cement mixture instead of the well-known concrete material. The two last decades, the properties of the soil mix material have been characterized by a lot of authors $[2,5,7,8,12,15,20,21]$. Concerning the use of soil mix material for the construction of retaining walls, information with regard to its hydromechanical characteristics can be found in the guidelines of BBRI and SBRCURnet [22] written on the basis of the results of the BBRI Soil Mix project (2009-2013) [18]. This project was initiated in 2009 by the Belgian Building Research Institute (BBRI) in collaboration with the KU Leuven and the Belgian Association of Foundation Contractors (ABEF). Financial support has been obtained from VLAIO, the Flemish government agency: Flanders Innovation and Entrepreneurship (http://www.vlaio.be/). Within the framework of this project, numerous tests on in-situ soil mix material have been performed [12]. Porosity, permeability, unconfined compressive strength (UCS) and tensile strength, as well as the modulus of elasticity, the ultrasonic pulse velocity and the adherence between soil mix material and steel reinforcement have been investigated. In addition, the results of petrographic analysis performed using thin section technology have also been published in order to obtain a microscopic view of the material [12].

\subsection{Laboratory tests on in-situ core samples and in-situ pull-out tests}

Table 1 presents typical hydro-mechanical properties for the soil mix material used for the construction of retaining walls for which the injected quantity of binder ranges between 200 and $450 \mathrm{~kg}$ of binder per $\mathrm{m}^{3}$, depending on the soil conditions, the execution process and the job specifications. The water/binder weight ratio typically varies between 0.6 and 1.2. The data of Table 1 come from 38 real Belgian construction sites, with different soil conditions and for various deep mixing systems (CSM, TSM and CVR C-mix systems).

Within the framework of the BBRI Soil Mix project (20092013) [18], a lot of different tests have been performed on core samples but in practice, it is not always possible to conduct tests for the determination of the modulus of elasticity or the tensile strength. UCS tests can be performed more easily and are less expensive. Table 2 summarizes different correlations, built on the basis of the UCS test results, that can be used for the determination of the mechanical properties of the soil mix material used for the construction of retaining walls

\subsection{Large-scale UCS and bending tests on real- scale soil mix elements}

In order to take into account the scale effect and the representativeness of the tests on core samples, large-scale UCS and bending tests have been performed within the framework of the BBRI Soil Mix project (2009-2013) [18]. These tests were conducted on real-scale soil mix panels and columns previously executed on real construction sites and excavated after a few days of hardening [23, 24, 25].

As illustrated in Fig. 4, large-scale UCS tests were conducted on rectangular blocks with approximately a square section, with a width corresponding to the width of the in-situ soil mix wall (about half a meter) and with a height approximately twice the width. After being excavated, soil mix elements from five construction sites have been tested. The details of the test procedure and results are given in [23, 24]. The major conclusion of this test campaign was the following: the real-scale UCS of the soil mix material is about $70 \%$ of the average UCS value obtained from tests on the typical core samples (10 cm diameter).

In order to determine the contribution of the soil mix material to the bending stiffness and to the bending resistance of the soil mix walls, seventeen large-scale bending tests, such as illustrated in Fig. 5, have been performed within the framework of the BBRI Soil Mix project (2009-2013) [18].

These large-scale bending tests were conducted on "realscale" reinforced soil mix elements (columns or panels) excavated from seven different job sites, with various soil conditions and for different execution processes (CVR C$\mathrm{mix}^{\circledast}$, TSM and CSM). The procedure and the results of this large-scale test campaign are described in detail in [24, 25] with the following main conclusions:

- The "real-scale" stiffness of the soil-mix element depends on the flexural moment applied to the soil mix wall. It decreases with increasing flexural moment as a consequence of the progressive opening of the cracks in the soil mix material. Actually, there is a progressive displacement of the neutral axis in the section when increasing the flexural moment. In the range of the flexural moments supported by the soil mix wall, the "real-scale" stiffness is significantly larger than the stiffness of the steel reinforcement only.

- The maximal flexural moment applied during the test (the moment at failure) is 1.8 to 3 times higher than the flexural moment corresponding to the yield strength of the steel beam (only considering the steel resistance).

- The measurement of the stresses in the two flanges of the steel beams demonstrates an efficient interaction between the soil mix material and the steel reinforcement: the yield strength was really reached (= measured) in the steel beams $\left(\sigma_{\text {measured }}=\sigma_{\text {yield strength }}\right)$ at bending moments 20 to $70 \%$ higher than without any contribution of the soil mix material. 
Table 1. Typical hydro-mechanical properties of the soil mix material used for the construction of retaining walls - data from the BBRI Soil Mix project (2009-2013) [12, 18].

Density of the soil mix material according to NBN EN 12390-7 - data based on 1074 test results obtained on cylindrical core samples (Height

$\mathrm{H}=$ Diameter $\mathrm{D}=10 \mathrm{~cm}$ ) from 38 job sites

\begin{tabular}{|l|l|l|l|l|}
\hline Soil type & Min value & Max value & Average value & Median value \\
\hline Clay & $1469 \mathrm{~kg} / \mathrm{m}^{3}$ & $2104 \mathrm{~kg} / \mathrm{m}^{3}$ & $1804 \mathrm{~kg} / \mathrm{m}^{3}$ & $1828 \mathrm{~kg} / \mathrm{m}^{3}$ \\
\hline Loam & $1582 \mathrm{~kg} / \mathrm{m}^{3}$ & $2054 \mathrm{~kg} / \mathrm{m}^{3}$ & $1774 \mathrm{~kg} / \mathrm{m}^{3}$ & $1753 \mathrm{~kg} / \mathrm{m}^{3}$ \\
\hline Sand & $1373 \mathrm{~kg} / \mathrm{m}^{3}$ & $2176 \mathrm{~kg} / \mathrm{m}^{3}$ & $1837 \mathrm{~kg} / \mathrm{m}^{3}$ & $1827 \mathrm{~kg} / \mathrm{m}^{3}$ \\
\hline
\end{tabular}

UCS of the soil mix material (at 28 days of hardening) according to NBN EN 12390-3 - data based on 1074 test results obtained on cylindrical core samples $(\mathrm{H}=\mathrm{D}=10 \mathrm{~cm})$ from 38 job sites

\begin{tabular}{|l|l|l|l|l|}
\hline & \multicolumn{2}{l|}{ UCS-average value } & \multicolumn{2}{l|}{ UCS-Characteristic value } \\
\hline Soil type & Wide range & Narrow range & Wide range & Narrow range \\
\hline Clay & $1.5-4.0 \mathrm{MPa}$ & $2.0-3.0 \mathrm{MPa}$ & $0.5-2.0 \mathrm{MPa}$ & $1.0-1.5 \mathrm{MPa}$ \\
\hline Loam & $2.0-5.0 \mathrm{MPa}$ & $2.5-4.0 \mathrm{MPa}$ & $0.75-3.0 \mathrm{MPa}$ & $1.25-2.0 \mathrm{MPa}$ \\
\hline Sand & $4.0-16.0 \mathrm{MPa}$ & $6.0-10.0 \mathrm{MPa}$ & $2.0-8.0 \mathrm{MPa}$ & $3.0-5.0 \mathrm{MPa}$ \\
\hline
\end{tabular}

Tensile splitting strength of the soil mix material according to NBN EN 12390-6 - data based on 95 test results obtained on cylindrical core samples $(H=D=10 \mathrm{~cm})$ from 15 job sites

\begin{tabular}{|l|l|l|l|l|}
\hline & Min value & Max value & Average value & Median value \\
\hline- & $0.16 \mathrm{MPa}$ & $2.28 \mathrm{MPa}$ & $0.91 \mathrm{MPa}$ & $0.89 \mathrm{MPa}$ \\
\hline
\end{tabular}

Modulus of elasticity of the soil mix material according to NBN B 15-203 - data based on 152 test results obtained on cylindrical core samples $(\mathrm{H}=20 \mathrm{~cm}, \mathrm{D}=10 \mathrm{~cm})$ from 32 job sites

\begin{tabular}{|l|l|l|l|l|} 
& Min value & Max value & Average value & Median value \\
\hline- & $2.129 \mathrm{GPa}$ & $23.800 \mathrm{GPa}$ & $7.975 \mathrm{GPa}$ & $6.761 \mathrm{GPa}$ \\
\hline
\end{tabular}

Steel-soil mix adherence - peak extraction resistance according to NBN EN 12504-3 - data based on the results of 25 in-situ pull-out tests performed on real soil mix elements from 4 job sites

\begin{tabular}{|l|l|l|l|l|}
\hline & Min value & Max value & Average value & Median value \\
\hline- & $0.20 \mathrm{MPa}$ & $3.40 \mathrm{MPa}$ & $1.03 \mathrm{MPa}$ & $0.87 \mathrm{MPa}$ \\
\hline
\end{tabular}

Porosity $^{\dagger}$ of the soil mix material according to NBN B15-215 - data based on 79 test results obtained on cylindrical core samples $(\mathrm{H}=\mathrm{D}=10$ $\mathrm{cm})$ from 15 job sites

\begin{tabular}{|l|l|l|l|l|} 
& Min value & Max value & Average value & Median value \\
\hline $\begin{array}{l}\text { No dependence on the soil } \\
\text { type }\end{array}$ & $29 \%$ & $63 \%$ & $48 \%$ & $50 \%$ \\
\hline
\end{tabular}

Coefficient of hydraulic conductivity of the soil mix material according to DIN 18130-1 - data based on 59 test results on cylindrical core samples $(\mathrm{H}=\mathrm{D}=10 \mathrm{~cm})$ from 16 job sites

\begin{tabular}{|l|l|l|l|l|}
\hline & Min value & Max value & Average value & Median value \\
\hline $\begin{array}{l}\text { No dependence on the soil } \\
\text { type }\end{array}$ & $3.5 \cdot 10^{-12} \mathrm{~m} / \mathrm{s}$ & $3.1 \cdot 10^{-9} \mathrm{~m} / \mathrm{s}$ & $2.9 \cdot 10^{-10} \mathrm{~m} / \mathrm{s}$ & $7.6 \cdot 10^{-11} \mathrm{~m} / \mathrm{s}$ \\
\hline
\end{tabular}

Ultrasonic pulse velocity of the soil mix material according to ASTM C597-09- data based on 198 test results on cylindrical core samples (D $=10 \mathrm{~cm}, \mathrm{H} / \mathrm{D}=1$ or 2 ) from 6 job sites

\begin{tabular}{|l|l|l|l|l|}
\hline & Min value & Max value & Average value & Median value \\
\hline & $2069 \mathrm{~m} / \mathrm{s}$ & $3481 \mathrm{~m} / \mathrm{s}$ & $2580 \mathrm{~m} / \mathrm{s}$ & $2517 \mathrm{~m} / \mathrm{s}$ \\
\hline
\end{tabular}

tfrom a microscopic analysis of a thin section cut in a soil mix core, it was observed that the high values of porosity were only related to the high and homogeneous capillary porosity (only $2.4 \%$ of macropores - pores with a surface area higher than $10 \mu \mathrm{m}^{2}-$ were observed). This high capillary porosity could result from the high water/cement ratio used for the execution of the soil mix element. The high hydration level and the presence of portlandite $\mathrm{Ca}(\mathrm{OH}) 2$ in the samples confirm this assumption [12].

The creep of the soil mix material was not considered in this test campaign due to the limited duration of the load steps applied during the bending tests [24, 25].

\section{Design of soil mix walls for earth and water retaining structures}

On the basis of the test results of the BBRI Soil Mix project (2009-2013) [18], a design methodology, in line with the structural Eurocodes, was developed for the soil mix retaining walls and published in the BBRI/SBRCURnet soil mix handbook [22].

In order to design a soil mix retaining wall, the designer has to consider the following design steps:
- the computation of the design values of the mechanical properties of the soil mix material,

- the verification of the arching effect,

- the assessment of the bending stiffness of the soil mix wall,

- the structural design of the soil mix wall.

The main principles of these design stages are summarized in the following paragraphs. The following considerations are only valid for soil mix elements reinforced with a steel beam (reinforcement cages are not considered in the present design approach). 
Table 2. Typical correlations that can be used for the first assessment of the properties of the soil mix material used for the construction of retaining walls.

\begin{tabular}{|c|c|c|}
\hline Parameter & Sources and correlations & \\
\hline $\begin{array}{l}\text { Age of the } \\
\text { specimen (days) }\end{array}$ & $\begin{array}{l}\text { BBRI Soil Mix Project (2009-2013) [18] } \\
\text { Laboratory sand-cement samples } \\
\mathrm{UCS}_{7 \text { days }}=0.37 \mathrm{UCS}_{28 \text { days }} \\
\mathrm{UCS}_{56 \text { days }}=1.13 \mathrm{UCS}_{28 \text { days }} \\
\mathrm{UCS}_{126 \text { days and more }}=1.46 \mathrm{UCS}_{28 \text { days }} \\
\text { Laboratory loam-cement samples } \\
\mathrm{UCS}_{7 \text { days }}=0.28 \mathrm{UCS} \mathrm{CS}_{28 \text { days }} \\
\mathrm{UCS}_{56 \text { days }}=1.31 \mathrm{UCS}{ }_{28 \text { days }} \\
\mathrm{UCS}_{126 \text { days and more }}=1.67 \mathrm{UCS}_{28 \text { days }}\end{array}$ & $\begin{array}{l}\text { Topolnicki }(2004)[7] \\
U_{C S}{ }_{4 \text { days }}=0.5 \mathrm{UCS}_{28 \text { days }} \\
\mathrm{UCS}_{7 \text { days }}=0.65-0.70 \mathrm{UCS}_{28 \text { days }} \\
\text { (silt and clay) } \\
\mathrm{UCS}_{7 \text { days }}=0.5-0.65 \mathrm{UCS}_{28 \text { days }} \\
\text { (sand) } \\
U C S_{56 \text { days }}=1.4-1.5 \mathrm{UCS}_{28 \text { days }} \\
\text { (clay and silt) }\end{array}$ \\
\hline $\begin{array}{l}\text { Shear strength } \\
\text { (MPa) }\end{array}$ & $\begin{array}{l}\text { Topolnicki (2004) [7] } \\
\tau=0.40-0.50 \text { UCS for UCS }<1 \mathrm{MPa} \\
\tau=0.30-0.35 \text { UCS for } 1<\text { UCS }<4 \mathrm{MPa} \\
\tau=0.20 \text { UCS for UCS }>4 \mathrm{MPa}\end{array}$ & $\begin{array}{l}\text { Porbaha et al. (2000) [20] } \\
\tau=0.53+0.37 \text { UCS }-0.0014 \text { UCS }^{2} \text { for UCS }<6 \mathrm{MPa}\end{array}$ \\
\hline $\begin{array}{l}\text { Tensile strength } \\
\text { (MPa) }\end{array}$ & $\begin{array}{l}\text { Denies et al. (2012) [12] } \\
\mathrm{T} \approx 0.1 \text { UCS }\end{array}$ & $\begin{array}{l}\text { Topolnicki (2004) [7] } \\
\mathrm{T}=0.08-0.15 \text { UCS with a maximal value of } 0.2 \mathrm{MPa}\end{array}$ \\
\hline $\begin{array}{l}\text { Modulus of } \\
\text { elasticity (MPa) }\end{array}$ & $\begin{array}{l}\text { Denies et al. (2012) [12] } \\
\text { †Tangent } \mathrm{E}_{10 \% \text { to } 30 \% \text { UCs }} \approx 1482 \mathrm{UCS}^{0.8} \\
\text { or } \\
\text { †Tangent } \mathrm{E}_{10 \% \text { to } 30 \% \mathrm{Ucs}} \approx 1000 \text { UCS } \\
\text { in first approximation }\end{array}$ & $\begin{array}{l}\text { Topolnicki (2004) [7] } \\
\text { ¥Secant } E_{50 \%} \text { UcS }=50-300 \text { UCS } \\
\text { for UCS }<2 \mathrm{MPa} \\
\text { Secant } E_{50 \%} \text { UCS }=300-1000 \text { UCS } \\
\text { for UCS }>2 \mathrm{MPa}\end{array}$ \\
\hline
\end{tabular}

TE is determined in a tangent way varying the applied load between $10 \%$ and $30 \%$ of the estimated UCS - the modulus of elasticity is deduced from measurements directly taken on the core sample (with LVDTs, DEMEC mechanical strain gages or electrical strain gages) and not considering the relative displacement of the plates of the hydraulic press

$\neq \mathrm{E}$ is determined in a secant way at $50 \%$ of the UCS

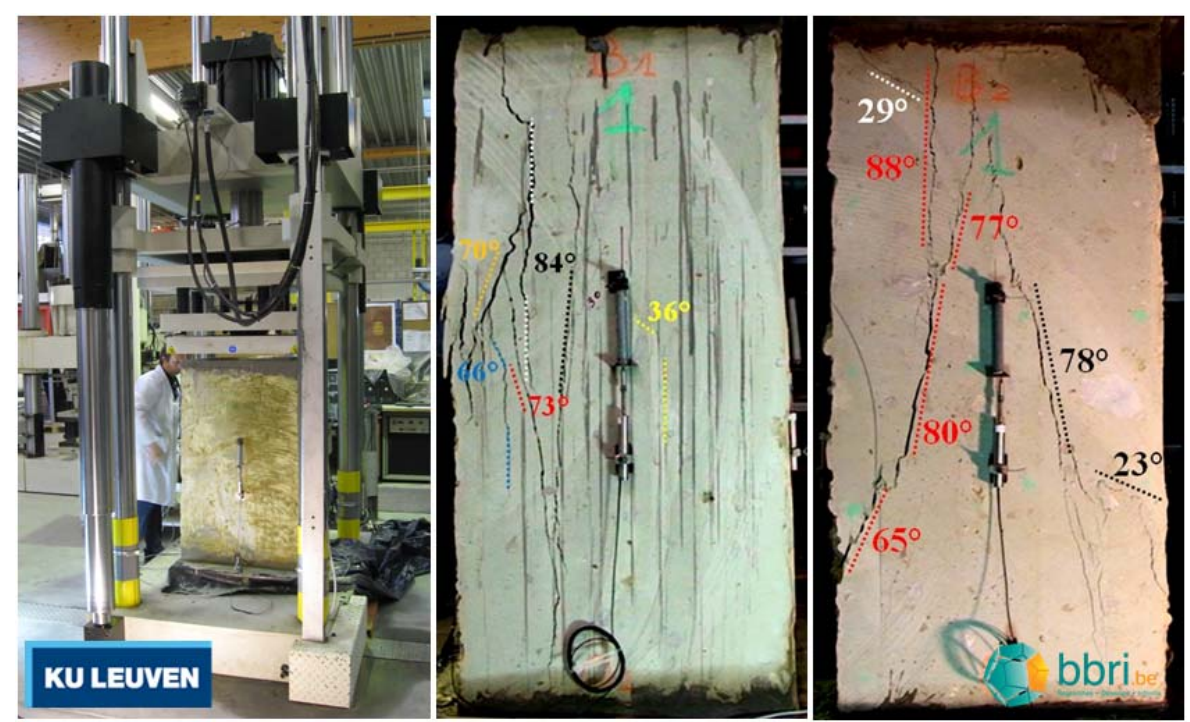

Figure 4. Large-scale UCS test performed on real-scale soil mix element within the framework of the BBRI Soil Mix project (2009-2013) [23, 24]

\subsection{Mechanical properties of the soil mix material for the design of soil mix walls}

The main parameters necessary for the design of a soil mix wall are the design values and the characteristic values of the UCS of the soil mix material, its tensile strength, its shear strength, its modulus of elasticity and its adherence with the steel reinforcements. For earth-water retaining walls, the permeability of the soil mix material has also to be assessed. A methodology for the computation of design values for these parameters is given in [22].

\subsection{Verification of the arching effect}

As explained in $[22,26]$, the verification of the arching effect is related to the distance between the steel beams (noted $I_{s}$ in Fig. 3). 


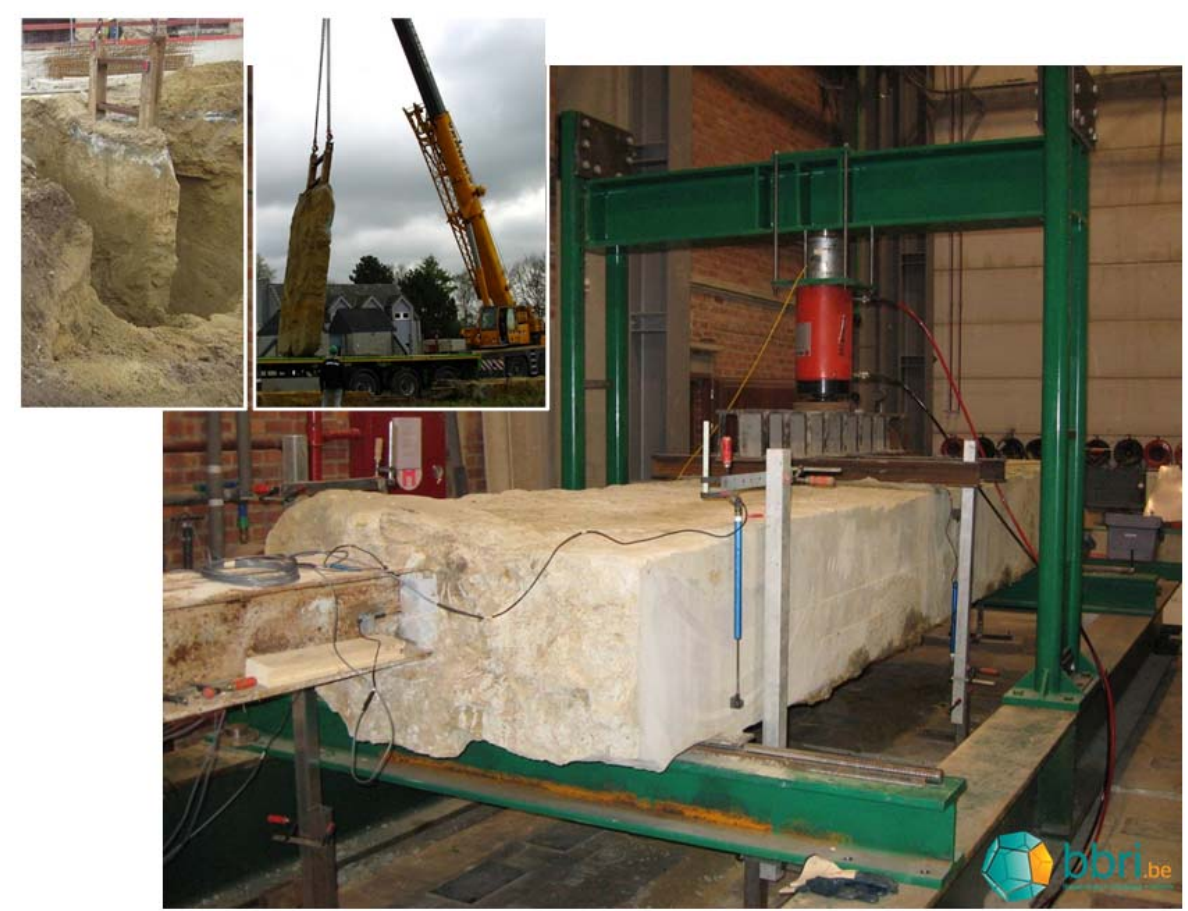

Figure 5. Large-scale bending tests performed on real-scale soil mix elements (columns or panels) within the framework of the BBRI Soil Mix project (2009-2013) [24, 25].

Table 3. Bending moment in a temporary soil mix panel (thickness $55 \mathrm{~cm}$ ) reinforced with steel beams (type HEA - steel grade S235).

\begin{tabular}{|c|c|c|c|c|c|c|c|c|c|}
\hline \multicolumn{10}{|c|}{ Resistance of the soil mix wall in terms of bending moment $\left(\mathrm{kN} / \mathrm{L}_{\text {eff }}{ }^{\gamma}\right)$} \\
\hline \multicolumn{10}{|c|}{$\mathrm{I}_{\mathrm{s}}=1.1 \mathrm{~m}, \mathrm{~L}=5 \mathrm{~m}$, eccentricity of the steel beam of $5 \mathrm{~cm}$ (= execution tolerance) } \\
\hline & HEA220 & HEA240 & HEA260 & HEA280 & HEA300 & HEA320 & HEA340 & HEA360 & HEA400 \\
\hline $\mathrm{M}(\mathrm{Rd}, \mathrm{a}, \mathrm{el})^{+}$ & 121.1 & 158.6 & 196.6 & 238.1 & 296.1 & 347.6 & 394.3 & 444.4 & 543.1 \\
\hline $\mathrm{M}(\mathrm{Rd}, \mathrm{a}, \mathrm{pl})^{\ddagger}$ & 133.6 & 175.0 & 216.2 & 261.3 & 325.0 & 382.6 & 434.8 & 490.7 & 602.1 \\
\hline $\mathrm{M}(\mathrm{Rd}, 2)^{*}$ & 140.3 & 180.0 & 218.4 & 263.6 & 325.0 & 382.6 & 434.8 & 490.7 & 602.1 \\
\hline$M(R d, 4)$ & 149.6 & 190.0 & 228.9 & 274.9 & 335.6 & 392.4 & 443.7 & 498.7 & 608.0 \\
\hline $\mathrm{M}(\mathrm{Rd}, 6)$ & 152.3 & 194.5 & 235.5 & 283.4 & 344.6 & 401.7 & 453.4 & 508.7 & 618.5 \\
\hline \multicolumn{10}{|c|}{ Contribution of the soil mix material to the bending resistance in comparison with the "elastic method" } \\
\hline $\mathrm{M}(\mathrm{Rd}, \mathrm{a}, \mathrm{el})$ & $100 \%$ & $100 \%$ & $100 \%$ & $100 \%$ & $100 \%$ & $100 \%$ & $100 \%$ & $100 \%$ & $100 \%$ \\
\hline$M(\mathrm{Rd}, \mathrm{a}, \mathrm{pl})$ & $110 \%$ & $110 \%$ & $110 \%$ & $110 \%$ & $110 \%$ & $110 \%$ & $110 \%$ & $110 \%$ & $111 \%$ \\
\hline $\mathrm{M}(\mathrm{Rd}, 2)$ & $116 \%$ & $113 \%$ & $111 \%$ & $111 \%$ & $110 \%$ & $110 \%$ & $110 \%$ & $110 \%$ & $111 \%$ \\
\hline $\mathrm{M}(\mathrm{Rd}, 4)$ & $124 \%$ & $120 \%$ & $116 \%$ & $115 \%$ & $113 \%$ & $113 \%$ & $113 \%$ & $112 \%$ & $112 \%$ \\
\hline $\mathrm{M}(\mathrm{Rd}, 6)$ & $126 \%$ & $123 \%$ & $120 \%$ & $119 \%$ & $116 \%$ & $116 \%$ & $115 \%$ & $114 \%$ & $114 \%$ \\
\hline
\end{tabular}

${ }^{\gamma}$ Effective length = average distance between the steel beams

${ }^{\dagger} \mathrm{M}(\mathrm{Rd}, \mathrm{a}, \mathrm{el})$ is the bending moment computed with an "elastic method" considering only the steel beam resistance

${ }^{\ddagger} \mathrm{M}(\mathrm{Rd}, \mathrm{a}, \mathrm{pl})$ is the bending moment computed with a "plastic method" considering only the steel beam resistance

* $\mathrm{M}(\mathrm{Rd}, 2 \mathrm{MPa})$ is the bending moment computed considering a contribution of the soil mix material to the bending resistance with a UCS characteristic value of $2 \mathrm{MPa}$ for the soil mix material

This distance has to be limited to ensure the arching effect according to the principles of Eurocode 2 (EN 1992-1-1) [27]:

$$
l_{s}<3 H
$$

where $l_{s}$ is the distance between the steel beams and $H$ the maximal height available for the development of the arch in the soil mix material (see Fig. 3).
As illustrated in detail in [22], the arching behavior is verified according to Eurocode 2 [27] by an iterative procedure varying the angle of the arch by assuming a parabolic function for the central line of the arch (red line in Fig. 3). The arching stresses arising in the soil mix material are then assessed and compared to the admissible value of the UCS of the soil mix material. 


\subsection{Assessment of the bending stiffness of the soil mix wall}

In the present design approach [22], two methods are proposed for the computation of the bending stiffness of the soil mix walls.

Based on a back analysis of the results of the large-scale bending tests [24, 25], the first method considers a "realscale" stiffness which takes into account the partial cracking of the soil mix material. An iterative process is applied to determine the position of the neutral axis during the loading of the soil mix wall and the "real-scale" bending stiffness is computed as:

$$
E I_{\text {Real }}=\frac{E I_{1}+E I_{2}}{2}
$$

where $E I_{1}$ is the stiffness taking into account the section of the uncracked soil mix material (compression zone) and $E I_{2}$ is the stiffness considering the section of the cracked soil mix material (tensile zone).

The second method is a simplified approach. The "real-scale" bending stiffness is determined as the sum of the stiffness of the steel reinforcement and the stiffness of the compressive zone of the soil mix section (assuming that the neutral axis is located in the middle of the steel beam):

$$
E I_{\text {Real }}=E I_{S}+E_{S M}\left[\frac{b_{c 1}\left(\frac{H_{S M}}{2}\right)^{3}}{3}\right]
$$

where $E I_{S}$ is the bending stiffness of the steel beam only, $E_{S M}$ is the modulus of elasticity of the soil mix material, $b_{c 1}$ is the effective width and $H_{S M}$ is the thickness of the soil mix wall. $b_{c 1}$ is computed as:

$$
b_{c 1}=\frac{L}{4}
$$

where $L$ is the distance between two zero moment points along the wall. Moreover, $b_{c 1}$ has to be limited to the distance between the steel beams: $b_{c 1}<l_{s}$. In practice, $b_{c 1}$ is generally equal to $l_{s}$.

Equations [2] and [3] are given for an effective width $\left(b_{c 1}\right)$. The use of equation [3] generally results in values of bending stiffness 10 to $20 \%$ lower than those computed with equation [2].

Using equations [2] and/or [3] for the assessment of a "realscale" bending stiffness, the introduction of low and high values of bending stiffness in numerical programs is irrelevant. Different verifications can possibly be performed at different depths in function of the potential variation of the modulus of elasticity of the soil mix material with depth.

\subsection{Structural design of the soil mix wall}

Up to now, the structural design of the soil mix wall (= assessment of the normal forces, shear forces and moments in the soil mix wall) was only based on the resistance of the steel beam. But with regard to the large-scale bending tests
$[24,25]$ and considering the principles of Eurocode 4 (EN 1994-1-1) [28], a method has been proposed in [22] to determine the bending moments in the soil mix wall taking into account the characteristics of the steel and soil mix materials. The result of this method is presented in the form of design tables such as illustrated in Table 3 for a soil mix panel reinforced with steel beam (type HEA). The contribution of the soil mix material results in a reduction of the stress in the steel beams. The bending moments obtained with this approach are 110 to $126 \%$ higher than those obtained with an "elastic method" only considering the yield strength of the steel beams. If normal forces additionally apply on the soil mix retaining wall, interaction diagrams, such as represented in Fig. 6 , can be used. The interaction between steel and soil mix can only be considered in the structural design of temporary applications (lifetime $<2$ years) because the creep of the soil mix was not considered during the large-scale bending tests [24, 25]. Hence, the bending moments of permanent soil mix walls (lifetime $>2$ years) will be computed only on the basis of the steel resistance. In the present design approach [22], the shear forces in the soil mix wall are computed only on the base of the steel resistance in agreement with EN 1993-1-1 [29]. In the handbook [22], requirements are given with regard to the execution tolerances and to the quality control of the final product in function of the application of the soil mix wall (temporary or permanent, retaining, bearing, cutoff functions).

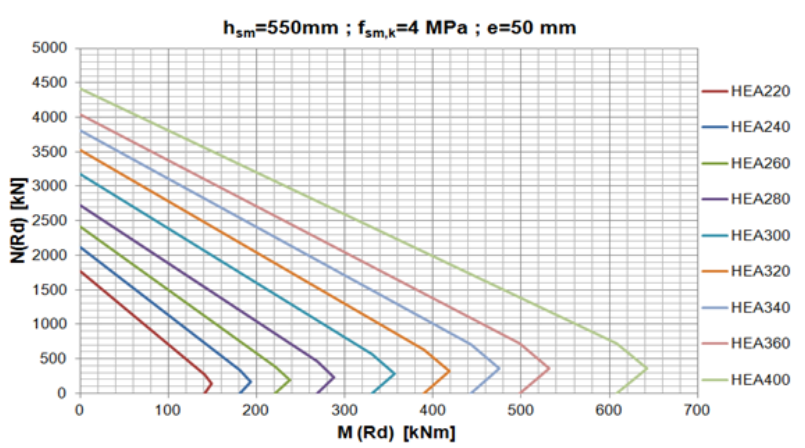

Figure 6. Interaction diagram for the design of a temporary soil mix panel (thickness $55 \mathrm{~cm}$ ) reinforced with steel beams (type HEA steel grade S235) for a UCS characteristic value of $4 \mathrm{MPa}$ for the soil mix material and an execution tolerance of $5 \mathrm{~cm}$ for the positioning of the steel beam, according to $[22,28]$

\section{Conclusions and perspectives}

In the present paper, the authors have presented test results characterizing the soil mix material as used for the construction of earth-water retaining walls within the framework of excavation works. In addition, a design methodology in line with the Eurocodes, such as proposed in [22], is explained. It is based on the results of the BBRI Soil Mix project (2009-2013) [18] and takes into account the function of the soil mix wall (earth-water retaining, bearing and cut-off functions) and its lifetime: temporary ( $<2$ years) or permanent ( $>2$ years) application. Based on the results of seventeen large-scale bending tests performed on real soil mix elements [24, 25], the design methodology considers the 
input of the soil mix material to the bending stiffness of the soil mix wall (for the temporary walls and for the permanent walls with a protection barrier) and to its structural resistance (only for the temporary applications). An example of a design table is given for a CSM panel reinforced with HEA steel beams. Similar design tables can be provided for other configurations in [22]. Finally, considering the input of the soil mix material in the structural design of the soil mix walls, the decrease of the stress in the steel beams results in a steel reduction ranging between 10 to $38 \%$ according to the design approach presented in the BBRI/SBRCURnet handbook [22].

If large advances have been performed in this field of engineering, areas for further R\&D still remain concerning:

- the influence of the deep mixing equipment on the final product,

- the minimal mixing energy to be used during execution to obtain an homogeneous material,

- the durability of the soil mix material (notably if it is used in polluted soils) although information already exists in the scientific literature (Guimond-Barrett [30], RUFEX [31], Denies et al. [32] and Helson [33]),

- the identification of chemicals possibly present in the soil influencing the binding reactions, the hardening process and the durability of the soil mix material,

- the alkaline-character of the soil mix material and its potential ability to protect steel reinforcements against corrosion,

- the ways to protect the soil mix wall against frost, carbonation and wet/dry cycles if the wall is exposed to the ambient air,

- the behavior of the soil mix wall in case of fire,

- the bearing capacity of the soil mix elements used as alternative to pile foundation or as rigid inclusion,

- the tensile behavior of the soil mix elements,

- the use of reinforcement cages in place of beams,

- the development of design methods in agreement with the Eurocodes for other fields of applications of the technique (e.g. global mass stabilization and reinforcement of land levees)

Further research actions are thus needed to improve our understanding of the behavior of the "reinforced" soil mix material particularly in those new fields of applications.

\section{Acknowledgements}

This research was financially supported by the Flanders Innovation and Entrepreneurship agency of the Flemish Region VLAIO (BBRI Soil Mix project, 2009-2013 [18]) and by the FPS Economy and the NBN, the Bureau for Standardization.

\section{References}

[1] M. Terashi, Theme lecture: Deep mixing method - Brief state of the art. Proceedings of the 14th International Conference of Soil Mechanics and Foundation Engineering, Hambourg (Germany), 6-12 September 1997, 1997, Vol. 4, 2475-2478.
[2] D.A. Bruce, M.E.C. Bruce, A.F. DiMillio, Deep mixing method: a global perspective. Soil Improvement for big digs, Boston (Massachusetts, USA), 18-21 October 1998, ASCE, Geotechnical special publication (1998) 81: 1-26.

[3] A. Porbaha, State of the art in deep mixing technology: part I. Basic concepts and overview. Ground Improvement (1998) 2: 81-92. https://doi.org/10.1680/gi.1998.020204

4] FHWA-RD-99-167 (2001). An introduction to the Deep Soil Mixing Methods as used in geotechnical applications: verification and properties of treated soil. Prepared by Geosystems (D.A. Bruce) for US Department of Transportation, FHWA (2001).

[5] CDIT - Coastal Development Institute of Technology, The Deep Mixing Method - Principle, Design and Construction. A. A. Balkema Publishers Lisse/Abingdon/Exton (PA)/Tokyo, 2002.

[6] M. Terashi, The State of Practice in Deep Mixing Methods. Grouting and Ground Treatment, 3rd International Specialty Conference on Grouting and Ground Treatment, New Orleans (Louisiana, USA), 1012 February 2003, ASCE, Geotech SP (2003) 120: 25-49. https://doi.org/10.1061/40663(2003)2

[7] M. Topolnicki, In situ soil mixing. M.P. Moseley, K. Kirsch (Eds.), Ground Improvement, 2nd ed., Spon Press, 2004.

[8] M. Kitazume, State of Practice Report - Field and laboratory investigations, properties of binders and stabilized soil. Internationa Conference on Deep Mixing, Stockholm (Sweden), 23-25 May 2005, 2005, Vol. 2, 660-684.

[9] S. Larsson, State of practice report - Execution, monitoring and quality control, International Conference on Deep Mixing, Stockholm (Sweden), 23-25 May 2005, 2005, Vol. 2, 732-785.

[10] C. Rutherford, G. Biscontin, J.-L. Briaud, Design manual for excavation support using deep mixing technology. Texas A\&M University, 2005.

[11] G. Filz, T. Adams, M. Navin, A.E. Templeton, Design of Deep Mixing for Support of Levees and Floodwalls. Grouting and Deep Mixing, New Orleans (Louisiana, USA), 15-18 February 2012, ASCE, Geotech SP (2012) 228 (1): 89-133. https://doi.org/10.1061/9780784412350.0004

[12] N. Denies, N. Huybrechts, F. De Cock, B. Lameire, A. Vervoort, G. Van Lysebetten, J. Maertens, Soil Mix walls as retaining structures mechanical characterization. International Symposium of ISSMGE TC211. Recent research, advances \& execution aspects of ground improvement works. N. Denies, N. Huybrechts (Eds.), Brussels (Belgium), 31 May-1 June 2012, 2012, Vol. 3, 99-115.

[13] N. Denies, G. Van Lysebetten, General Report - Session 4 - SOIL MIXING 2 - DEEP MIXING. International Symposium of ISSMGE TC211. Recent research, advances \& execution aspects of ground improvement works, Brussels (Belgium), 31 May-1 June 2012, 2012, Vol. I, 87-124.

[14] FHWA-HRT-13-046 (2013), Federal Highway Administration Design Manual: Deep Mixing for Embankment and Foundation Support. US Department of Transportation, FHWA (2013).

[15] M. Kitazume, M. Terashi, The Deep Mixing Method. CRC Press/Balkema. Taylor and Francis Group, London, 2013.

[16] N. Denies, N. Huybrechts, Deep Mixing Method: Equipment and Field of Applications. Ground Improvement Case Histories, Book chapter 11, Elsevier, 2015, 311-350. https://doi.org/10.1016/B978-0-08-100191-2.00011-3

[17] Eurosoilstab, Development of design and construction methods to stabilise soft organic soils. Design Guide Soft Soil Stabilisation. EC project BE 96-3177 (2002).

[18] BBRI 'Soil Mix' project (2009-2013), VLAIO (formerly IWT) 080736 soil mix project: SOIL MIX in constructieve en permanente toepassingen - Karakterisatie van het materiaal en ontwikkeling van nieuwe mechanische wetmatigheden. For additional information: [12].

[19] EN 14679 - 2005. Execution of special geotechnical works - Deep mixing.

[20] A. Porbaha, S. Shibuya, T. Kishida, State of the art in deep mixing technology. Part III: geomaterial characterization. Ground Improvement (2000) 3: 91-110. https://doi.org/10.1680/grim.2000.4.3.91

[21] N. Denies, G. Van Lysebetten, Summary of the Short Courses of the IS-GI 2012. Latest advances in Deep Mixing. International Symposium of ISSMGE - TC211. Recent research, advances \& execution aspects of ground improvement works, Brussels (Belgium), 31 May-1 June 2012, 2012, Vol. V, 73-123.

[22] BBRI/SBRCURnet, Handboek soilmix-wanden, SBRCURnet/WTCB publicatie, juni 2016, ISBN 978905367616 5, www.sbrcurnet.nl (in dutch). 
[23] A. Vervoort, A. Tavallali, G. Van Lysebetten, J. Maertens, N. Denies, N. Huybrechts, F. De Cock, B. Lameire, Mechanical characterization of large scale soil mix samples and the analysis of the influence of soil inclusions. International symposium of ISSMGE - TC211. Recent research, advances \& execution aspects of ground improvement works. Brussels (Belgium), 31 May-1 June 2012, 2012, Vol. III, 127135.

[24] N. Denies, G. Van Lysebetten, N. Huybrechts, F. De Cock, B. Lameire, J. Maertens, A. Vervoort, Real-Scale Tests on Soil Mix Elements. Proceedings of the DFI-EFFC International Conference on Piling and Deep Foundations, Stockholm (Sweden), 21-23 May 2014, 2014, 647-656.

[25] N. Denies, N. Huybrechts, F. De Cock, B. Lameire, J. Maertens, A. Vervoort, Large-scale bending tests on soil mix elements. International Foundations Congress and Equipment Expo 2015, San Antonio (Texas, USA), 17-21 March 2015, ADSC, DFI, ASCE G-I Institute and PDCA, 2015, 2394-2409.

https://doi.org/10.1061/9780784479087.222

[26] N. Denies, N. Huybrechts, F. De Cock, B. Lameire, J. Maertens, A. Vervoort, J. de Leeuw, F. Hoefsloot, Design and quality control of soil mix walls for earth and water retaining structures. Proceedings of the Deep Mixing conference 2015, San Francisco (California, USA), 25 June 2015, DFI publications, 2015, 35-44.

[27] EN 1992-1-1 - 2004. Eurocode 2: Design of concrete structures Part 1-1: General rules and rules for buildings.

[28] EN 1994-1-1 - 2005. Eurocode 4: Design of composite steel and concrete structures - Part 1-1: General rules and rules for buildings.

[29] EN 1993-1-1 - 2005. Eurocode 3: Design of steel structures - Part 11: General rules and rules for buildings.

[30] Guimond-Barrett, A. Influence of mixing and curing conditions on the characteristics and durability of soils stabilised by deep mixing. PhD thesis Université du Havre. 2013.

[31] Projet RUFEX. Renforcement et réutilisation des plateformes ferroviaires et des fondations existantes. Deep Soil Mixing - Guide pour le traitement des sols. 2014 (in French).

[32] N. Denies, N. Huybrechts, F. De Cock, B. Lameire, J. Maertens, A. Vervoort, A. Guimond-Barrett, Thoughts on the durability of the soil mix material. ICE Publishing - Proceedings of the XVI ECSMGE Geotechnical Engineering for Infrastructure and Development, 2015, 1403-1408.

[33] Helson, O. Comportement mécanique et physique des bétons de sol : étude expérimentale paramétrique, prédictive, et de durabilité. Thèse de doctorat. Université de Cergy-Pontoise. 2017 (in French). 